\title{
Study on Histopathological Correlation with ER, PR, and HER 2 Neu Receptor Status in Breast Carcinoma and its Prognostic Importance
}

\author{
Mahendra Singh $^{1}$, Jagdish Kumar ${ }^{2 *}$, Anita Omhare ${ }^{3}$, Vandana Mishra ${ }^{4}$, Chayanika Kala ${ }^{5}$ \\ ${ }^{1}$ Professor and Head, Department of Pathology, G. S. V. M. Medical College, Kanpur, U.P, India \\ ${ }^{2}$ Junior Resident, Department of Pathology, G. S. V. M. Medical College, Kanpur, U.P, India \\ ${ }^{3,4}$ Assistant Professor, Department of Pathology, G. S. V. M. Medical College, Kanpur, U.P, India \\ ${ }^{5}$ Assistant Professor, Department of Pathology, L. P. S. Institute of cardiology, Kanpur, U.P, India
}

*Address for Correspondence: Dr. Jagdish Kumar, Junior Resident, Department of Pathology, G. S. V. M. Medical College, Kanpur, India

E-mail: kumarjagdish791@gmail.com

Received: 03 Sep 2018/ Revised: 15 Oct 2018/ Accepted: 17 Dec 2018

\begin{abstract}
Background: Carcinoma breast is the most common malignancy occurring in females worldwide while in India it is the $2^{\text {nd }}$ most common malignancy occurring after cervical cancer in females. The incidence is three times higher in urban areas than in rural setup. The disease pattern, clinical and histopathological presentation differs from that of the western world.

Methods: The present study was carried out in the Department of Pathology, G.S.VM. Medical College Kanpur, India from July 2016 to August 2018. Total 54 female were considered for the study, selected on the basis of inclusion and exclusion criteria. Histomorphology and lymph node status in breast carcinomas, the status of estrogen receptor (ER), progesterone receptor (PR) and human epidermal growth factor receptor 2 (HER2/neu) in all these breast carcinomas and its prognostic importance in post operative patient.

Results: Present study comprised of total 54 female patients. Out of all $48.15 \%$ cases were found to be in $5^{\text {th }}$ decade (premenopausal predilection) of life in our setup. Most common type found in study was Ductal carcinoma (not otherwise specified) seen in $92.6 \%$ cases. Lymph node metastasis was found in $66 \%$ positive cases. Maximum $54 \%$ cases were histologically classified as grade II. A positive correlation was found between histology and immunohistochemistry.

Conclusion: From the present study, it can be concluded that there is a positive correlation between histopathological grade and other prognostic factors including immunohistochemical markers. Immunohistochemical markers can be effectively used to predict prognosis and therapeutic management of patients with carcinoma breast.
\end{abstract}

Key-words: Breast Carcinoma, Histological Grading, Immunohistochemistry, Estrogen Receptor (ER), Progesterone Receptor (PR), Human Epidermal Growth Factor Receptor 2 (HER2/neu)

\section{INTRODUCTION}

Breast carcinoma is the most common malignant tumor and the leading cause of carcinoma death in women. In our country, though the incidence of breast carcinomas is lower than the west yet it is the second most common

\section{How to cite this article}

Singh $M$, Kumar J, Omhare A, Mishra V, Kala C. Study on Histopathological Correlation with ER, PR, and HER 2 Neu Receptor Status in Breast Carcinoma and its Prognostic Importance. SSR Inst. Int. J. Life. Sci., 2019; 5(1): 2130-2136.

\begin{tabular}{|c|c|}
\hline & Access this article online \\
\hline
\end{tabular}

malignant tumor in females comprising 16 to $21 \%$. The first being carcinoma cervix breast cancers are diagnosed at a relatively advanced stage ${ }^{[1]}$. Breast cancer is the most common female cancer in the world with an estimated 1.67 million new cancer cases diagnosed in 2012. This represents about $12 \%$ of all new cancer cases and $25 \%$ of all cancers in women ${ }^{[2]}$. Annual incidence of approximately 1, 44,000 new cases of breast cancers in India, it has now become the most common female cancer in urban India and the second commonest in the rural Indian women.

Currently, routine clinical management of breast cancer incorporates specific molecular markers; namely Estrogen Receptor (ER), Progesterone Receptor (PR), 
Human Epidermal Growth Factor Receptor 2 (HER2) gene that have been proven to provide therapeutic, predictive and prognostic value. The triple negative breast cancer (ER/PR/HER-2/neu) has the worst overall survival.

\section{MATERIALS AND METHODS}

The present study was carried out in the Department of Pathology, G.S.VM. Medical College Kanpur, India from July 2016 to august 2018. Total 54 female were considered for the study, selected on the basis of inclusion and exclusion criteria. We included in our study histomorphology and lymph node status in breast carcinomas, the status of estrogen receptor (ER), progesterone receptor $(\mathrm{PR})$ and human epidermal growth factor receptor 2 (HER2/neu) in all these breast carcinomas and its prognostic importance in postoperative patient. Tumor mass was subjected to immunohistochemistry. The above study was approved by the institutional ethical committee and informed consent was obtained from the patients prior to the study. The Modified Scarf's Bloom-Richardson for Histopathological grading ${ }^{[3]}$ and Allred scoring system used for estrogen receptors ${ }^{[4]}$. HER2/neu staining is graded from 0 - 3+; with no staining or membrane staining in more than $10 \%$ of tumor cells graded as 0 and strong complete membrane staining in more than $30 \%$ of tumor cells as $3+.0-1$ is negative; $2+, 3+$ is positive according to ASCO/CAP (American Society of Clinical Oncology and the College of American Pathologist) ${ }^{[5]}$.

\section{Inclusion criteria}

1. Mastectomy specimens of clinically/cytological diagnosed breast malignancy in the female of all age group.

2. Patients who gave written informed consent.

\section{Exclusion criteria}

1. Patients with metastatic malignancy of breast.

2. Patients already treated for contra lateral breast cancer.

3. Patients not willing to give written consent.

\section{RESULTS}

The above Table 1 shows that peak incidence of breast cancer is in the $5^{\text {th }}$ decade i.e. 26 cases $(48.15 \%)$. Closely followed by $6^{\text {th }}$ decade in which 14 cases $(25.93 \%)$ were reported.
Table 1: Age distribution of patients with Breast cancer

\begin{tabular}{ccc}
\hline Age group (Yrs) & $\begin{array}{c}\text { No. of cases } \\
(\mathbf{n}=\mathbf{5 4})\end{array}$ & $\begin{array}{c}\text { Percentage } \\
\text { (\%) }\end{array}$ \\
\hline$<30$ & 1 & 1.85 \\
$31-40$ & 6 & 11.11 \\
$41-50$ & 26 & 48.15 \\
$51-60$ & 14 & 25.93 \\
$61-70$ & 5 & 9.26 \\
$>70$ & 2 & 3.70 \\
Total & 54 & 100 \\
\hline
\end{tabular}

Table 2: Histomorphological distribution of malignant breast lesions

\begin{tabular}{ccc}
\hline Type & No. of cases & Percentage \\
\hline $\begin{array}{c}\text { Ductal carcinoma } \\
\text { (NOS) }\end{array}$ & 50 & 92.60 \\
$\begin{array}{c}\text { Malignant phyllodes } \\
\text { tumor }\end{array}$ & 1 & 1.85 \\
$\begin{array}{c}\text { Lobular carcinoma } \\
\text { Mucinous } \\
\text { carcinoma } \\
\text { Medullary } \\
\text { carcinoma } \\
\text { Total }\end{array}$ & 1 & 1.85 \\
\hline
\end{tabular}

The most common type found in the study was Ductal carcinoma (not otherwise specified) seen in $92.6 \%$ cases. Only 50 cases classified as Ductal carcinoma (NOS) were included in this analysis.

Table 3: Distribution of cases according to tumor size

\begin{tabular}{ccc}
\hline Tumor size $(\mathbf{c m})$ & $\begin{array}{c}\text { No. of cases } \\
(\mathbf{n}=\mathbf{5 0})\end{array}$ & Percentage (\%) \\
\hline$<2$ & 08 & $16 \%$ \\
$2-5$ & 30 & $60 \%$ \\
$>5$ & 12 & $24 \%$ \\
\hline
\end{tabular}

12 cases had tumor more than $5 \mathrm{~cm}$ i.e. $24 \%$ (T3), $60 \%$ had tumor size 2 to $5 \mathrm{~cm}$ (T2) and $16 \%$ cases had tumor size between 1 to $2 \mathrm{~cm}$ (T1). 
Table 4: Distribution of cases according to lymph node status

\begin{tabular}{ccc}
\hline Lymph node status & No. of cases $(\mathbf{n}=\mathbf{5 0})$ & Percentage \\
\hline Not identified & 10 & 20 \\
Negative (0) & 07 & 36 \\
Positive (1-3) & 18 & 30 \\
Positive ( 4 or more) & 15 & \\
\hline
\end{tabular}

Lymph node metastasis was found in $66 \%$ positive cases.

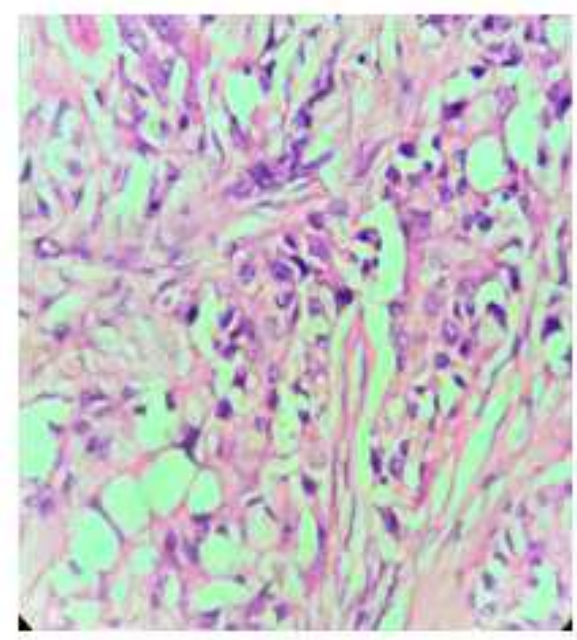

IDC Grade I (H \& E 400x)

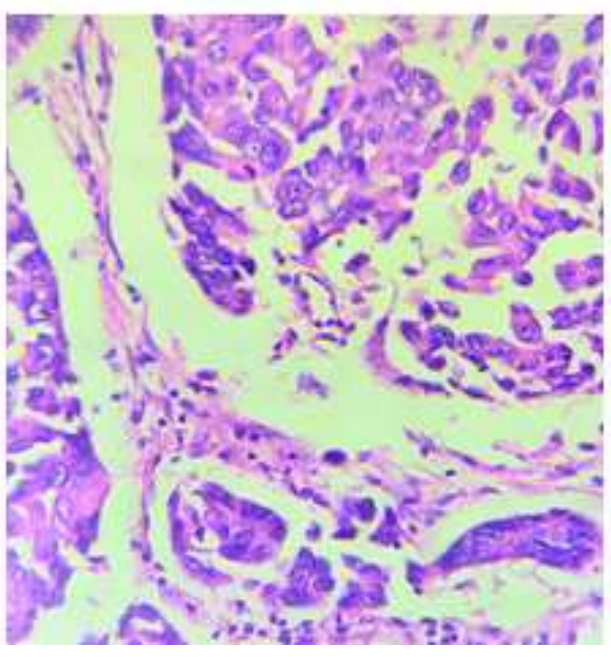

IDC Grade II (H \& E 400x)

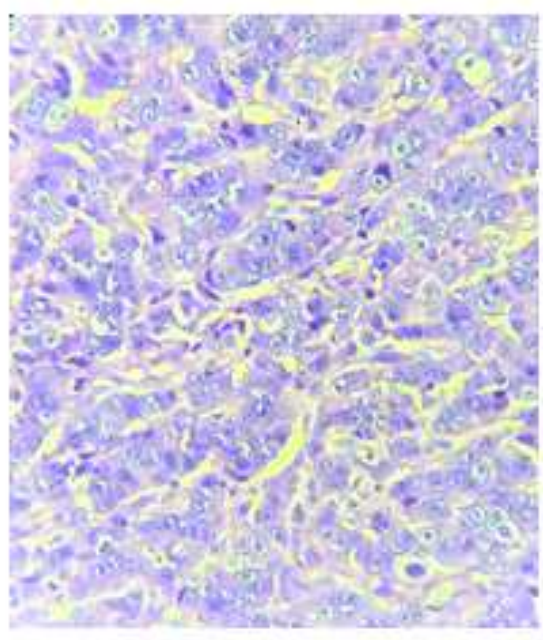

IDC Grade III (H \& E 400x)

Fig. 1: Histological grades of Breast carcinoma

Table 5: Distribution of cases according to modified Bloom Richardson's Grade

Histological grade

I

II

III
No. of cases $(n=50)$

10

27

13
Percentage

20

54

26

Maximum 54\% cases were histologically classified as grade II.

Table 6: Distribution of cases based on Estrogen, Progesterone \& HER 2 neu receptor

\begin{tabular}{ccc}
\hline Receptor & $\begin{array}{c}\text { No. of cases }(\mathbf{n}=\mathbf{5 0}) \\
\text { Estrogen }\end{array}$ & $\%$ \\
\hline Positive & 28 & $56 \%$ \\
Negative & 22 & $44 \%$ \\
& Progesterone & $38 \%$ \\
Positive & 19 & $62 \%$ \\
Negative & 31 &
\end{tabular}




\section{HER 2 neu}

Positive

- $56 \%$ cases were ER-positive, while $44 \%$ cases are ER negative.

- $38 \%$ cases were PR-positive and $62 \%$ cases were PR negative

- $30 \%$ cases were Her 2 neu positive and $70 \%$ were negative.

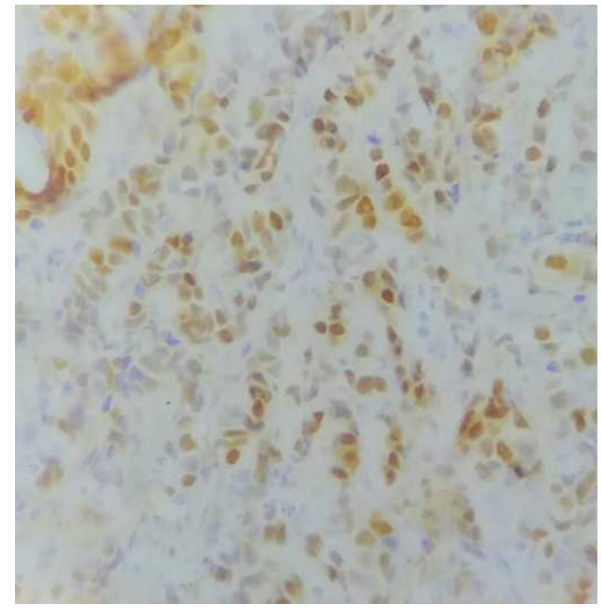

ER Positivity (100x)

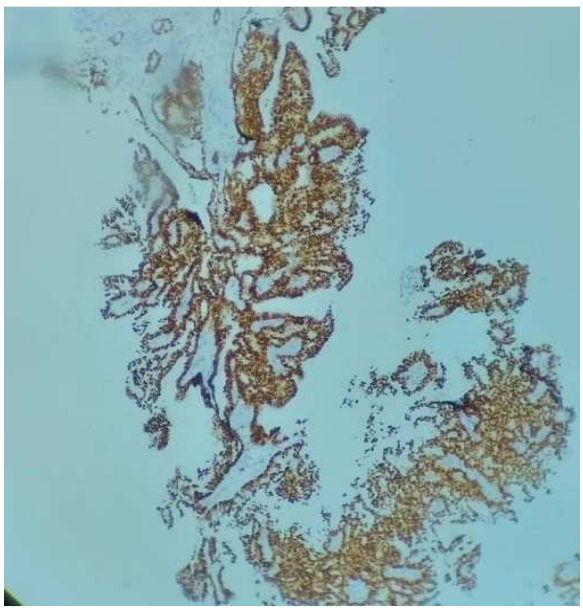

PR Positivity (100x)

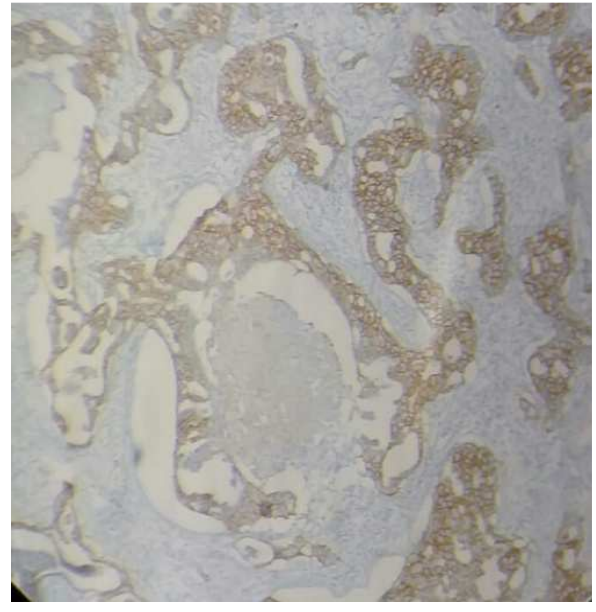

Her 2 neu Positivity (100x)

Fig. 2: Immunohistological Status

Table 7: Distribution of Cases Based on ER, PR, HER 2 neu positive and triple negative cases according to Grade of tumor

\begin{tabular}{|c|c|c|c|c|c|}
\hline Grade of tumor & $\begin{array}{c}\text { No. of cases } \\
\qquad(n=50)\end{array}$ & ER positive cases & PR positive Cases & $\begin{array}{c}\text { HER } 2 \text { neu } \\
\text { positive cases }\end{array}$ & $\begin{array}{c}\text { Triple negative } \\
\text { cases }\end{array}$ \\
\hline I & 10 & 8 & 7 & 3 & 0 \\
\hline II & 27 & 19 & 11 & 9 & 6 \\
\hline III & 13 & 1 & 1 & 3 & 9 \\
\hline
\end{tabular}

Most of the tumors of grade I \& II were ER positive, while most of the grade III tumors were ER negative. Most PR positive cases were from grade I \& II, while most cases of grade III tumor were PR negative. Overall Few cases were shown HER 2 neu positive.

Table 8: Relation between histological and molecular classes ( $N=50)$

\begin{tabular}{ccccc}
\hline Histological grade & Luminal A & Luminal B & $\begin{array}{c}\text { HER 2 neu over } \\
\text { expression }\end{array}$ & Triple negative \\
\hline Grade 1 & 7 & 2 & 1 & 0 \\
Grade 2 & 7 & 8 & 6 & 6 \\
Grade3 & 1 & 0 & 3 & 9 \\
\hline
\end{tabular}


15 cases were classified as luminal a, 10 cases as luminal b. 10 cases show HER 2 neu over expression and 15 cases were classified as triple negative. After applying chi

Table 9: Relation between patient's age and molecular classes $(\mathrm{N}=50)$ square test, no significant association between age and molecular subtypes was seen.

\begin{tabular}{ccccc}
\hline Age of patient & Luminal A & Luminal B & HER 2 neu over expression & Triple negative \\
\hline$<45$ yrs & 7 & 5 & 6 & 8 \\
$>45$ yrs & 8 & 5 & 4 & 7 \\
\hline
\end{tabular}

\section{DISCUSSION}

Age group- This study shows that peak incidence of breast cancer is in the $5^{\text {th }}$ decade i.e. 40 cases $(48.15 \%)$. Closely followed by $6^{\text {th }}$ decade in which 20 cases (25.93\%) were reported which is comparable to other studies done previously ${ }^{[6-9]}$.

Tumor size- 12 (24\%) cases have tumor size>5 cms. $30(60 \%)$ cases were having $2-5 \mathrm{cms}$, and 8 (16\%) cases were having less than $2 \mathrm{cms}$ in size ${ }^{[10]}$. Study shows that mean size of the lesion was $3.3 \mathrm{~cm}$. Majority of our cases $(60 \%)$ had tumor size of $>2$ to $5 \mathrm{~cm}$. Other studies also recorded the majority of patients presenting with tumor size of 2 to $5 \mathrm{~cm}$. (24\%) cases had tumor size of greater than $5 \mathrm{~cm}$ at presentation ${ }^{[11,12]}$.

Lymph node status- About $66 \%$ cases have metastatic lymph node half of them are having $>4$ metastatic lymph node. In developed countries, in majority of patients lymph node was not involved, but studies carried out in India documented a greater percentage of breast carcinoma with lymph nodal metastasis compared to western figures. In the study cases with lymph node involvement was $74.3 \%$. same were observed previous studies ${ }^{[13-15]}$. Most common histological type is invasive ductal carcinoma (NOS) comprises $90 \%$ of total cases, which is similar to other Indian studies.

Histological types and grades- Most common histological type is invasive ductal carcinoma (NOS) comprise $92.6 \%$ of total cases, which is similar to other Indian studies. 54\% cases belongs to grade II of Bloom Richardson grading, while $26 \%$ and $20 \%$ cases belonged to grade III and grade I respectively, which is comparable to other studies ${ }^{[12,16-19] .}$

Hormonal receptor status- $56 \%$ cases shows ER positive and $44 \%$ cases shows ER negative, however $38 \%$ cases shows PR positive and $62 \%$ cases are PR negative. $30 \%$ cases are HER 2 neu positive and 70\% cases are HER 2 neu negative $30 \%$ cases are triple negative. Most of the grade 1 and 2 tumors were ER positive and most of the cases of grade 3 were ER negative. Most of the studies noted the relatively higher percentage of estrogen and progesterone positivity ${ }^{[14-23]}$. Among molecular Luminal A type constitutes 30\%, Luminal B 20\%, HER 2 neu enriched $20 \%$ and Triple negative cases $30 \%$. ${ }^{[15]}$. Our study also shows an inverse relationship between expression of HER 2 neu and estrogen/progesterone, still a substantial amount (20\%) cases were triple positive ${ }^{[20]}$. Most of the grade 1 and 2 tumors are PR positive and most of the cases of grade 3 are PR negative. It was observed in this study that Grade III tumors, in $90 \%$ of cases have unfavorable hormone receptor status, in contrast to Grade I and Grade II tumors, which shown association with favorable hormone receptor status. In this study, most common molecular subtype was luminal A representing $30 \%$. We were observed a proportion of Her-2/neu subtype (20\%) than previously reported in the literature ${ }^{[14]}$. There was no correlation found between molecular type of breast cancer and age of the patients ${ }^{[14]}$. Majority of cases of luminal A, luminal $B$, and normallike subtypes had less number of lymph node (1-3) involvement while in Her-2/neu and basal-like phenotype majority of cases had more number of lymph node (4-9) involvement ${ }^{[14]}$. Luminal A had lower tumor grade while Her-2/neu positive and basal-type phenotype are associated with higher grade tumors. This association was found to be statistically significant ${ }^{[14]}$. Luminal B, Her-2/neu and basal-like are associated with higher stage than luminal A, which are associated with earlier stage. Majority of tumors of grade 1 were ER, PR positive and majority of grade 3 tumors were triple negatives, which exemplifies the fact that higher the grade, lower is the hormone receptor expression. This 
study highlights the importance of grading and hormone receptor status evaluation. Grading highly correlates with the survival rate and receptor status predicts the response to hormonal therapy. Histopathological grading put together with receptor status offers an excellent method of correlation of survival rate and response to hormonal therapy.

\section{CONCLUSIONS}

Carcinoma of the breast is a common clinical problem in our society. The present study shown invasive ductal carcinoma is most common histological type prevalent in Indian population but at an early age compared to western countries. The patients presenting at an early age were associated with higher grades of a tumor along with over expression of HER 2 neu and triple negative cases. It was also found that large tumor size, high Nottingham modification of Bloom-Richardson grade were usually associated with Luminal B, HER 2/neu positive and triple negative phenotype than luminal $A$. As the traditional histological classification were not able to evaluate the biological behavior of the different breast tumors, molecular classification of breast cancer is useful for clinical management and superior to the histological classification in short term prognostic value. Different immunophenotypes respond differently to different therapies. Luminal groups respond to hormonal treatment, while HER 2/neu group responds well to biological therapies using transtuzumab. On the other hand, basal like phenotype, usually respond well to chemotherapy.

In the light of the above findings and the availability of newer drugs, hormonal therapy and biological therapies, this type of classification must be investigated and taken into account when assessing response to these treatments.

\section{ACKNOWLEDGMENTS}

All authors very thankful to the Department of Pathology, G. S. V. M. Medical College Kanpur, India for help in writing the paper.

\section{CONTRIBUTION OF AUTHORS}

Research concept- Dr. Mahendra Singh, Dr. Jagdish kumar

Research design- Dr. Jagdish kumar

Supervision- Dr. Mahendra Singh
Materials- Anita Omhare, Vandana Mishra, Chayanika Kala

Data collection- Dr. Jagdish kumar

Data analysis- Dr. Jagdish kumar

Literature search- Dr. Jagdish kumar

Writing article- Dr. Jagdish kumar

Critical review- Dr. Mahendra Singh

Article editing- Anita Omhare, Vandana Mishra, Chayanika Kala

Final approval- Dr. Mahendra Singh, Dr. Jagdish kumar

\section{REFERENCES}

[1] Agarwal G, Ramakant P. Breast Cancer Care in India: The Current Scenario and the Challenges for the Future. Breast Care (Basel), 2008; 3(1): 21-27.

[2] Mittal A, Prasad C, Sreeramulu P, Srinivasan D, Khan NA, et al. Histopathological Grade versus Estrogen and Progestron Receptor Status in Carcinoma BreastA Single Center Study. J. Surg., 2017; 4(3): 555-639.

[3] Rosai J. Breast. In: Rosai and Ackerman's Surgical Pathology. ${ }^{\text {th }}$ ed. Noida: Reed Elsevier India Private Limited. 2009; pp. 1787-827.

[4] Fitzgibbons PL, Murphy DA, Hammond ME, Allred DC, Valenstein PN. Recommendations for validating estrogen and progesterone receptor immunohistochemistry assays. Arch., Pathol, Lab Med., 2010; 134(6): 930-35.

[5] Wolff AC, Hammond ME, Schwartz JN, Hagerty KL, Allred DC, et al. American Society of Clinical Oncology/College of American Pathologists guideline recommendations for human epidermal growth factor receptor 2 testing in breast cancer. Arch. Pathol. Lab Med., 2007; 131(1): 18-43.

[6] Sledge GW. Cancer research in the developing world. $41^{\text {st }}$ Annual Meeting of ASCO 2005. Educational book, 2005: 698-71.

[7] Agarwal G, Pradeep PV, Agarwal V, Yip CH, Cheung PS. Spectrum of breast cancer in Asian women. World J. Surg., 2007; 31(5): 1031-40.

[8] Murthy NS, Agarwal UK, Chaudhry K, Saxena S. A study on time trends in incidence of breast cancerIndian scenario. Eur. J. Cancer Care (Engl.), 2007; 16(2): 185-86.

[9] Mohammad HF, Foreman KJ, Delossantos AM, Lozano R, Lopez AD, et al. Breast and cervical cancer in 187 countries between 1980 and 2010: A systematic analysis. The Lancet, 2011; 378(9801): 1461-84. 
[10]Nabi MG, Ahangar A, Kaneez S. Estrogen Receptors, Progesterone Receptors and their Correlation with respect to HER-2/neu Status, Histological Grade, Size of Lesion, Lymph node Metastasis, Lymphovascular Involvement and Age in Breast Cancer patients in a hospital in North India. Asian J. Med., 2016; 7(3): 28-34.

[11]Shrigondekar P, Desai S, Bhosale S, Mankar D, Badwe A. Study of hormone receptor status of breast carcinoma and its correlation with the established prognostic markers. Int. J. Health Sci. Res., 2012; 1: 109-16.

[12]Sofi GN, Nabi J, Nadeem R, Khan FA, Sofi AA, et al. Estrogen receptor and progesterone receptor status in breast cancer in relation to age, histological grade, size of lesion and lymph node involvement. Asian Pacific J. Cancer Prev., 2012; 13: 5047-52.

[13]Tiwari S, et al. Breast Cancer: Correlation of Molecular Classification with Clinicohistopathology. Sch. J. App. Med. Sci., 2015; 3(2G): 1018-26.

[14]Munjal K, Ambaye A, Evans MF, Mitchell J, Nandedkar $\mathrm{S}$, et al. Immunohistochemical Analysis of $\mathrm{ER}, \mathrm{PR}, \mathrm{Her} 2$ and $\mathrm{CK} 5 / 6$ in Infiltrative Breast Carcinomas in Indian Patients. Asian Pacific J. Cancer Prev., 2009; 10: 773-78.

[15]Ambroise M, Ghosh M, Mallikarjuna VS, Kurian A. Immuno-histochemical Profile of Breast Cancer Patients at a Tertiary Care Hospital in South India. Asian Pacific J. Cancer Prev., 2011; 12: 625-29.

[16]Geethamala K, Murthy VS, Vani BR, Rao S. Hormone receptor expression in breast carcinoma at our hospital: An experience. Clin. Cancer Investig. J., 2015; 4: 511-15.
[17]Nikhra P, Patel S, Taviad D, Chaudhary S. Study of ER (EstrogenReceptor), PR (Progesterone Receptor) \& HER-2/NEU (Human Epidermal Growth Factor Receptor) expression by immunohistochemistry in breast carcinoma. Int. J. Biomed. Adv. Res., 2014; 05: 275-78.

[18]Ghosh J, Gupta S, Desai S, Shet T, Radhakrishnan S, et al. Estrogen, progesterone and HER2 receptor expression in breast tumors of patients, and their usage of HER2-targetedtherapy, in a tertiary care centre in India. Indian J. Cancer, 2011; 48: 391-96.

[19]Vasudha B, Jha B, Patel P. Correlation of hormonal receptor and Her-2/neu expression in breast carcinoma: A study at tertiary care hospital in Gujarat. Natl. J. Med. Res., 2012; 2(3): 295-98.

[20]Nisa A, Bhurgri $Y$, Raza F, Kayani N. Comparison of ER, PR, and HER-2/neu (C-erb B 2) reactivity pattern with histological grade, tumor size and lymph node status in breast cancer. Asian Pacific J. Cancer Prev., 2008; 9: 553-56.

[21]Puvitha RD, Shifa S. Breast Carcinoma, Receptor Status and Her2 neu Expression Revisited. Int. J. Sci., Stud., 2016; 3(10): 52-58.

[22]Kumar V, Abbas AK, Aster JC. Robbins and Cotran Pathologic basis of Disease. $9^{\text {th }}$ edition. (Vol.2). Philadelphia, USA: Elsevier Saunders; 2014; 1051-68.

[23]Lakmini K, Mudduwa B. Quick score of hormone receptor status of breast carcinoma: Correlation with the other clinicopathological prognostic parameters. Indian J. Pathol. Microbiol., 2009; 52 (2): 159-63. 